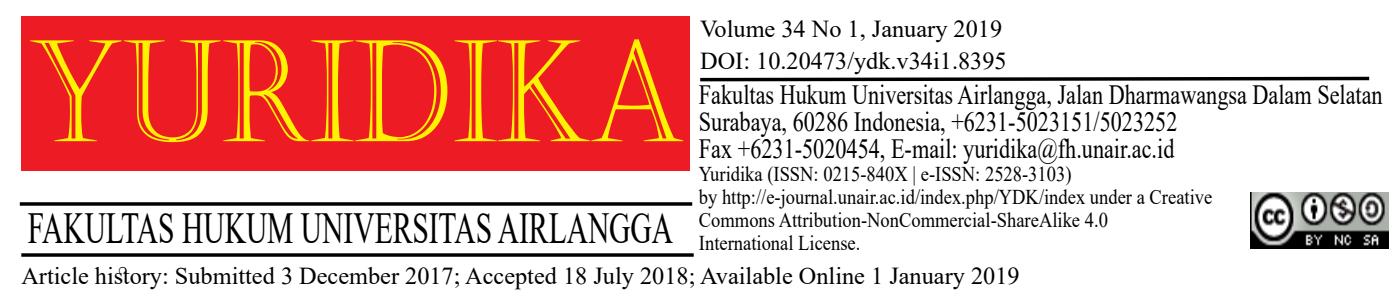

\title{
Authority of Government Internal Supervisory Apparatus in Licensing of Natural Resources to Prevent Corruption, Collusion and Nepotism
}

\author{
Iskandar \\ suttaniskandar@yahoo.com \\ University of Bengkulu
}

\begin{abstract}
The occurrence of $\mathrm{CCN}$ in the procedure of issuing natural resources licensing is partly caused by the weakness of supervision aspect. In fact, the purpose of supervision is basically intended to prevent the occurrence of $\mathrm{CCN}$. This paper is intended to examine the legal issue of how the regulation of the authority of the government's internal supervisor (GISA) is in performing the supervisory function based on the prevailing provisions, and how GISA's authority relates to the supervisory function in the natural resource licensing governance to prevent and eradicate $\mathrm{CCN}$. This is a normative juridical study analyzing the primary and secondary legal materials. The analysis is conducted by qualitative juridical. The result of the study shows that the authority of GISA in performing the function of general and technical supervision has been regulated in various regulations. However, related to appointment in position and responsibility mechanism of execution of task and function of GISA there is still a weakness, as it is done not in stages the results of performance are potentially not objective. The authority of GISA which specifically relates to supervisory functions in natural resource licensing has not explicitly been regulated in the existing regulations. However, GISA remains authorized to monitor the governance of natural resource licensing. Therefore, the issuance of all permit decisions including natural resource licensing is the implementation of government functions, while internal control in the administration of government functions belongs to GISA's authority.
\end{abstract}

Keywords: GISA; Licensing Governance; NaturalResources; CCN. 


\section{Introduction}

Good governance ${ }^{1}$ in the management of Natural Resources in Indonesia is still far beyond satisfactory results. Natural resources management has not been based on the principles of sustainable development yet. ${ }^{2}$ Management of natural resources is uncontrolled, unable to be done transparently, having secret access and no space for people to communicate, lack of accountability, and also commitment to coordinate. ${ }^{3}$ In addition, the licensing bureaucratic chain, and the low quality of government personnel mentality in natural resources governance also contribute to the destruction and loss of potential natural resources that are economically and ecologically harmful.

Good governance in the aspects of licensing law for natural resource has become very important, ${ }^{4}$ because without good governance, it will be an easy land for unscrupulous personnel to take advantage of personal and other benefits.

1 The concept of Good Governance relates to the activities of the implementation of functions to organize the public interest and closely connected with human rights.Oheo K.Haris, 'Aspek Hukum Pidana Dalam Kaitannya Dengan Perizinan Di Bidang Pertambangan’ (2014) 29 Yuridika $<$ https://e-journal.unair.ac.id/YDK/article/view/376>.Good Governance regarding the implementation of three basic tasks of the government are: 1) to guarantee the security off all person and society itself; 2) to manage an effective frame work for the public sector, the rivate sector, and civil society; 3) to promote economic, social and other aims in accordance with the wishes of the population, seeG.H. Addink, Reader, Principles of Good Governance (Faculty of Law, Economic, and Governance, University of Utrecht 2010).[13]. See also Oheo K.Haris, 'Good Governance (Tata Kelola Pemerintahan Yang Baik) Dalam Pemberian Izin Oleh Pemerintah Daerah Di Bidang Pertambangan' (2015) 30 Yuridika <https://e-journal.unair.ac.id/YDK/article/ view/4879>.[78]. The UN Commission on Human Rights identifies transparency as one of the key principles of good governance. The same thing is also mentioned by The Canadian International Development Agency that defines good governance is mirrored if the power of the organization (or government) one of them run with transparency. Meanwhile, The UN Development Program (UNDP) in 1997 suggested transparency in the policy-making process was one of the eight principles of good governance. In Indonesia alone, Law Number 28 Year 1998 on the Implementation of a Clean and Free State of Corruption, Collusion, and Nepotism says the principle of openness is one of the general principles of good state governance

2 Iskandar, Hukum Kehutanan, Prinsip Hukum Pelestarian Fungsi Lingkungan Hidup Dalam Kebijakan Pengelolaan Kawasan Hutan Berkelanjutan (Mandar Maju 2015).[226].

3 UNDP, 'Indeks Tata Kelola Hutan' (Industri bisnis, 2014) <http://industri.bisnis.com/ $\mathrm{read} / 20150522 / 99 / 435928 /$ indeks-tata-kelola-hutan-2014-diluncurkan> accessed 5 January 2018. See also BAPPENAS, Indonesian Climate Change Sectoral Roadmap (ICCSR) Summary Report Forestry Sector, (BAPPENAS2010).[2]. And see Linda, 'Pengelolaan Sumber Daya Alam Yang Bertanggung Jawab' (Portal Pantauan Hutan, 2015) <http://fwatcher.fwi.or.id/pengelolaan-sumber-daya-alam-yang-bertanggung-jawab/\#_ftn2> accessed 5 January 2018.

4 Natural resource licensing, covering the forestry and environmental sectors, plantations, mining, marine and fisheries, and various other sectors. 
Improper governance of natural resource licensing will allow for unlawful acts of corruption, collusion and nepotism. ${ }^{5}$ Good governance in permit application services, among others in the form of integrated one-stop service policy, ease of licensing service, and other policies, should be directed to a good service, transparent and accountable, both in terms of authority, procedure and substance. Licensing in the natural resource sector is one of the legal instruments of the government that is to control the utilization of natural resources in order not to deviate from the applicable legal provisions, so as not to cause problems that could harm the State and environmental interests. ${ }^{6}$

Licensing instrument is an authority ${ }^{7}$ owned by the government as a means to supervise community activities. Licensing is more a preventive instrument or character as an instrumental preventive. ${ }^{8}$ In implementing the authority of the

${ }^{5}$ Several cases of corruption in the natural resource licensing sector, namely IUP corruption case issued by Nur Alam, Southeast Sulawesi see Restu Mulyana, 'Potensi Korupsi Di Bidang Perizinan' (harian.analisadaily.com, 2016) <http://harian.analisadaily.com/opini/news/potensi-korupsi-di- field-licensing/260241/2016/09/01> accessed 5 January 2018. In central Sulawesi, a bribery case related to a palm oil clearance by Tempo.co, 'Amran Batalipu of Buol Regent' (Tempo.co, $2017)<$ https://nasional.tempo.co/read/900315> accessed 26 September 2017.Rita Widyasari Regent Kutai Kertanegara stipulated KPK as a suspect related to the alleged acceptance of bribery and gratuity licensing. See Lusia Arumingtyas and Tommy Apriando, 'Ketika Bupati Rita Terjerat Dugaan Suap Izin Sawit Di Kutai Kertanegara' (Mongabay Situs Berita Lingkungan, 2017) <https://www. mongabay.co.id/2017/10/08/ketika-bupati-rita-terjerat-dugaan-suap-izin-sawit-di-kutai-kertanegara/> accessed 5 January 2018. Wali Kota Cilegon, Tubagus Iman Ariyadi was arrested by KPK for allegedly involving bribe of AMDAL recommendation (Kompas,24/9/2017), see Absori and Nunik Nurhayati, 'Kebijakan Perizinan, Sengketa Lingkungan Hidup dan Kepentingan Investasi' (2017) 7 Jurisprudence $<$ https://www.google.com/search?q= Absori+dan+Nunik+Nurhayati\%2C+"Kebijakan+Perizinan $\% 2 \mathrm{C}+$ Sengketa+Lingkungan+Hidupdan+Kepentingan+Investasi $\% 2 \mathrm{C}+(2017)+7+-$ Jurisprudence.\&rlz=1C1CHBD_idID823ID823\&oq=Absori+dan+Nunik+Nurhayati\%2C+"Kebijakan+Perizinan\%2C+Sengketa $>$. [99].

${ }^{6}$ Permission is actually a norm of prohibition, but with consent based on government regulatory powers it is permissible, of course, following the fulfillment of a number of conditions prescribed by the rules.

7 Conceptually, the term authority or authority is often paralleled by the term "bevoegdheid" meaning authority or power. Authority is a very important part in Administrative Law, because the new government can perform its functions on the basis of the authority it obtains. Philipus M. Hadjon, 'On the Authority of the Government (Bestuur Bevoegdheid)' (1998) XVI Pro Justitia. Meanwhile, according to Ateng Syafrudin, authority (authority, gezag) is different from authority (competence, bevoegheid). The authority only concerns a certain part of authority (onderdeel), within the authority there are authorities (recht bevoegheden), see Salim HS and Erlies Septiana Nurbani, Penerapan Teori Hukum Pada Penelitian Dan Disertasi (PT RadjaGrafindo Persada 2013).[184].

${ }^{8}$ Iskandar, 'Hukum Perizinan Sebagai Instrumen Pencegahan Kerusakan Sumber Daya Alam Dan Lingkungan Hidup', Orasi Ilmiah, 15 Oktober 2015 (Universitas Bengkulu 2015).[5]. 
issuance of natural resource licensing required professional officers, honest, open and free from money politics, so violation in procedure of issuing permit can be avoided. Although, in reality, there are still government officials who abuse their authority, ${ }^{9}$ to take personal advantage by doing money politics.

The occurrence of corruption, collusion and nepotism in the procedure of issuing permits by the government apparatus is partly due to the weakness of supervision aspects, ${ }^{10}$ both internal ${ }^{11}$ control and external ${ }^{12}$ supervision. In fact, the purpose of supervision is basically intended to prevent the occurrence of corruption, collusion, and nepotism. Through supervision, especially internal monitoring, it is expected that the licensing procedure can be run in accordance with prevailing regulations, effective and efficient and free of corruption, collusion and nepotism. ${ }^{13}$

Internal supervision is a supervisory process undertaken by an internal government, meaning that the supervisor is not separated from government agencies, has its own authority or authority in overseeing the running of the government by government bureaucratic apparatus. During this time, the government's internal supervisory apparatus (GISA) is known as inspectorate, namely Inspectorate General

\footnotetext{
9 Abuse of authority is in the concept of parallel administrative law with the concept of detournement de pouvoir. It means the use of authority not as it should be. Officials use their powers for other purposes that deviate from the purpose that has been granted to that authority, so that the official has violated the principle of specialties. In the abuse of authority there is no omission element, because it is done consciously divert the purpose for the benefit of private or others. Compare with Philipus M. Hadjon, 'PTUN Dalam Konteks UU No. 30 Tahun 2014 Tentang Adminstrasi Pemerintahan', Seminar Nasional: Administrative Law Update 2017 (Hyatt Regency Yoyakarta 2017).[9]

${ }^{10}$ Supervision is a process of activities aimed at ensuring that government runs efficiently and effectively in accordance with the plans and provisions of applicable legislation.

${ }^{11}$ Internal Supervision is the whole process of audit activities, review, evaluation, monitoring, and other oversight activities on the organization of duties and functions of the organization in order to provide reasonable assurance that the activities have been carried out in accordance with the benchmarks that have been established effectively and efficiently for the interests of the leadership in realizing good governance, see Article 1 point 3 of Government Regulation Number 60 Year 2008 on SPIP. Internal supervisors include Inspectorate General, Provincial Inspectorate/District/City, BPKP, Menpan-RB.

${ }_{12}$ External supervision is a supervisory process undertaken by agencies/institutions outside the government. External supervision includes BPK, DPR, DPRD, KPK, PTUN, Ombudsman, and NGO.

13 Compare with Fenty U Puluhulawa, 'Pengawasan Sebagai Instrumen Penegakan Hukum Pada Usaha Pertambangan Mineral Dan Batubara’ (2011) 11 Dinamika Hukum < http://dinamikahukum.fh.unsoed.ac.id/index.php/JDH/article/view/189>.[314].
} 
at the ministry/non-ministry, Provincial Inspectorate, Regency/City Inspectorate, Central and Local Environmental Supervisory Officials (PPLH and PPLHD), specifically to oversee the compliance of business men/activities in the environmental field. However, the oversight function by GISA is generally not maximized, especially related to the supervisory function in the field of natural resource licensing. ${ }^{14}$

In practice, the authority of GISA is more functioning in public treasury oversight or audits on the use of State and local budgets (APBN/APBD). Whereas the duties and functions of GISA are very broad not only do audit, review, monitoring, evaluation, but also it is good in other supervision activities in the form of socialization, assistance and consultancy. In fact, GISA is obliged to follow up public complaints, such as obstacles, delays, and/or low quality of public services, misuse of authority, budget and assets or state/regional property. ${ }^{15}$

The occurrence of unlawful acts in the process of licensing the natural resources sector, such as the case involving the Governor of Sulawesi Tenggara, the Regent of Buol, the Regent of Kutai Kertanegara, ${ }^{16}$ if GISA performs its duties and supervisory functions properly, such violation action can likely be prevented. Because the function of supervision is to prevent, therefore the unlawful acts should not be happening. GISA should be the first institution to detect such deviations and immediately give warning (early warning system). GISA should be an important

${ }^{14}$ As many as 85 percent of internal Supervisors in ministries, local government, regional inspectorates, and their staff have not been able to guarantee good governance Resty Armenia, 'Jokowi Kaget Terima Laporan Soal Kondisi Pengawasan Internal' (CNN Indonesia, 2015)<https://www. cnnindonesia.com/nasional/20150513151334-20-53103/jokowi-kaget-terima-laporan-soal-kondisi-pengawasan-internal> accessed 10 January 2018.

15 See the provisions of Article 49 of Government Regulation Number 60 Year 2008 on Government Internal Control System (SPIP), Article 10 and Article 16 of Government Regulation Number 12 Year 2017 on the Development and Supervision of Local Government Implementation, see also the provisions of Article 383, Article 385 of Law Number 23 Year 2014 regarding Regional Government.

${ }^{16}$ See citation number 5 Associated with the unlawful acts by this public official, proving what Lord Action states, "power tends to corrupt, but absolute power corrupts absolutely" (power tends to be abused and absolute power must be misused), either in form detournement de pouvoir and/or willekeur, or acts of lawlessness by the government (onrechmatige overheidsdaad) through the use of various forms of government action (bestuur handelingen) resulting in the loss of state and citizens, see also Bambang Arwanto, 'Perlindungan Hukum Bagi Rakyat Akibat Tindakan Faktual Pemerintah' (2016) 31 Yuridika <https://e-journal.unair.ac.id/YDK/article/view/4857>. [373]. 
instrument for the realization of a clean and free government organization of clean governance, including government actions in natural resource licensing governance.

The fact is that external supervisors (BPK, KPK, Police, and Attorney) are more often found violations of law by bureaucratic apparatus and officials, either through investigation process and investigation or through hand-caught operation (OTT). ${ }^{17}$ Such external supervisory measurements are more than repressive law enforcement and by regarding to unlawful acts which cause harm to the State's finances. This does not necessarily undermine the position of external control which also serves as checks and balances or as a government controller and reminder. It should be understood; however, that the position of the external supervisor is the second oversight watcher after the internal supervisor, if the internal supervisor is functioning properly, repressive law enforcement by the external supervisor (criminal law enforcement officers) is unnecessary, as it should be ultimum remedium or the ultimate cure.

Based on the above description, in relation to the authority of GISA in the governance of natural resource licensing it is necessary to conduct further study. This paper examines two legal issues, namely, first, how to regulate the authority of GISA in performing supervisory functions based on applicable provisions; second, how does GISA's authority relate to the supervisory function in natural resource governance to prevent and combat corruption, collusion, and nepotism practices? In accordance with prescriptive and applied legal characteristics, ${ }^{18}$ the purpose of this study is to describe the legal issue. The study is normative juridical, analyzing primary and secondary legal materials. The Primary legal materials, namely laws and regulations relating to GISA's authority arrangements and the secondary legal materials in the form of legal opinions, doctrines, and theories obtained from legal literature, research results, scientific articles, and websites related to GISA's duties

${ }^{17}$ Toto Pribadi, 'The Number of OTTs by the KPK, From 2005 to October 2017' (VIVA.co.id, 2017) <http://www.viva.co.id/berita/nasional/965440-daftar-ott-kpk-dari-tahun-ke-tahun-2017-paling-sibuk> accessed 10 January 2018.

18 Peter Mahmud, Penelitian Hukum (Kencana Prenada Media Group 2005).[22]. 
and functions. Analysis is done by qualitative juridical, the results of the analysis are described, then conclusions are drawn as answers to legal issues raised.

\section{The Regulation Related GISA Authority in Performing the Supervisory Function Based on the Prevailing Provisions}

The regulation related GISA authority are identified in the following terms: In Law Number 15 Year 2004 on Audit of Management and Responsibility of State Finance, mentioned in Article 9 paragraph 1 in conducting the audit of management and financial responsibility of the state, BPK may use GISA examination results. In paragraph 2 it is mentioned that the report of the examination result of GISA shall be submitted to BPK. In General Explanation of this act, explains that the authority of BPK to perform 3 (three) types of examination, That is: number 2 Performance examination, is an examination of economic and efficiency aspects, as well as examination of effectiveness aspects that are commonly done for the interests of management by GISA.

Article 1 Sub-Article 46 of Law Number 23 Year 2014 on Regional Government, states that GISA is the ministry's inspectorate general, the supervisory unit of non-ministerial government institution, provincial inspectorate, and district/ city inspectorate. Article 377 of the Regional Government Law states that the Minister shall conduct general supervision on the implementation of Provincial Government. Technical ministers and heads of non-ministerial government agencies carry out technical supervision of the implementation of the Provincial Government in accordance with their respective duties and coordinate with the Minister. Supervision is carried out by GISA in accordance with its functions and authorities. The Governor as the head of the provincial region shall be obliged to carry out guidance and supervision on the provincial regional apparatus. In carrying out the guidance and supervision of the Governor is assisted by the Provincial Inspectorate. ${ }^{19}$ The Regent/Mayor as the Head of the Regency/Municipal Region

\footnotetext{
19 See the provisions of Article 379 of the Regional Government Law.
} 
shall be obliged to carry out guidance and supervision on the regional apparatus of the district. In conducting guidance and supervision, the regents/mayors are assisted by the Regency/City Inspectorate. ${ }^{20}$

The public may submit complaints on allegations of irregularities committed by state civil apparatus in the Regional Agencies to GISA and/or law enforcement apparatus. GISA is obliged to examine allegations of irregularities reported by the public. Law enforcement officers conduct an examination of complaints submitted by the public, after first coordinating with GISA or non-ministerial government agencies in charge of supervision. If based on the results of the examination found evidence of administrative deviations, further process submitted to GISA. If based on the examination results found evidence of criminal deviation, the process would be further submitted to law enforcement officers in accordance with the provisions of legislation. ${ }^{21}$

Basically, administrative errors in the implementation of government functions cannot be criminally accountable. However, if the administrative error has an element of intent and consequently detrimental to the country's financial or economy carried out to enrich/benefit themselves or others, then it has fulfilled the element of nature against the criminal law of corruption. In relation to corruption criminal law, especially Article 3 of Law Number 31 Year 1999 concerning the Eradication of Corruption Crimes (UUPTPK) which has been amended by Law Number 20 Year 2001 on Amendments of Eradication of Corruption Crimes (UUPTPK), administrative violations can be the cause of the occurrence of unlawful conduct, if the elements are intentional (will and awareness) to benefit themselves by abuse of

\footnotetext{
${ }^{20}$ See the provisions of Article 380 of the Regional Government Law.

${ }^{21}$ See the provisions of Article 385 of the Regional Government Law., and also see the provisions of Article 20 of Law Number 30 Year 2014 concerning Government Administration (UUAP), that GISA is authorized to carry out the supervisory function. Possible GISA supervision methods are in the form of audit actions. Specifically related to the conclusion of the APIP supervision which states that there are administrative errors that cause state financial losses because of the presence or absence of abuse of authority, the audit is an audit with certain objectives that are incidental at the request of law enforcement officers.
} 
office power, which is therefore detrimental to the state's finances or economy. The implementation of government functions that meet these requirements will have the consequences of criminal liability, so that law enforcement will be carried out by criminal law enforcement officers.

On October 17, 2014, Law Number 30 Year 2014 on Government Administration (UUAP) was enacted. UUAP becomes the legal basis in governance as an effort to improve good governance and as an effort to prevent corruption, collusion and nepotism practices. Thus, UUAP must be able to create a better, transparent and efficient bureaucracy. UUAP becomes the legal basis needed as a base of the decisions and/or actions of government officials to meet the legal needs of the community in the administration of government.

Supervision of the prohibition of abuse of authority is committed by GISA. The results of GISA surveillance are no errors, administrative errors, or administrative errors that cause financial losses to the state. If the results of GISA supervision in the form of administrative errors, follow-up in the form of administrative improvements in accordance with the provisions of legislation. If the result of GISA supervision is in the form of an administrative error causing the state financial loss, then the state financial loss should be paid no later than 10 (ten) working days after the decision is made and the result of the supervision is issued. The state losses are imposed on the Governing Body, if an administrative error occurs not due to an element of abuse of Authority. Get returned to year state losses are imposed on Government Officials, if administrative errors occur due to an element of abuse of Authority. ${ }^{22}$

Supervision in the environmental field is regulated in Article 71 to 74 of Law Number 32 Year 2009 on Environmental Protection and Management (UUPPLH). The follow up of this provision is established by the Environmental Supervisory Official (PPLH) and the Regional Environmental Supervisory Official (PPLHD). PPLH and PPLHD are GISA which is authorized to examine and know the level of compliance of the party responsible for activities and/or business against the

\footnotetext{
${ }^{22}$ See the provisions of Article 20 of the UUAP.
} 
provisions of legislation related to environmental issues, including compliance with aspects of environmental permit. ${ }^{23}$ In addition, based on the findings of supervision, GISA may also calculate the potential losses of the State and environmental losses as stipulated by Regulation of the Minister of Environment Number 7 Year 2014 on Environmental Losses Due to Pollution and/or Environmental Degradation.

In regarding to this internal control is also regulated in Government Regulation Number 60 Year 2008 on Government Internal Control System (SPIP). In Article 48 paragraph 2 mentioned that GISA perform internal supervision through a. audit; b. review; c. evaluation; d. monitoring; and e. other surveillance activities. Article 49 states that GISA consists of: a. BPKP; b. The Inspectorate General or any other name functionally exercising internal control; c. Provincial Inspectorate; and d. Regency/City Inspectorate. BPKP exercises internal control over the accountability of state finances for certain activities which include: $a$. cross-sectoral activities; $b$. general treasury activities of the state based on the stipulation by the Minister of Finance as State General Treasurer; and c. other activities based on the assignment of the President. Inspectorate General or other names functionally carrying out internal supervision shall supervise all activities in the context of the implementation of duties and functions of ministries of state/institutions funded by APBN (state and local budgets). The Provincial Inspectorate shall supervise all activities in the context of the implementation of the tasks and functions of the provincial local government-funded provincial work unit. The Inspectorate of the Regency/ Municipality shall supervise all activities in the framework of the implementation of duties and functions of the regency/city working units funded by the State and local budgets (APBN/APBD).

In Article 16 of Government Regulation Number 12 Year 2017 concerning the Development and Supervision of the Implementation of Regional Government, it is affirmed that, paragraph 2 GISA exercises supervision on local governance based on

\footnotetext{
${ }^{23} \mathrm{PPLH} / \mathrm{PPLHD}$ in some countries called environmental inspectors are people conducting inspection or environmental inspection activities. Hamrat Hamid and Bambang Pramudyanto, Pengawasan Industri Dalam Pengendalian Pencemaran Lingkungan (1st edn, Granit 2007).[34].
} 
professional principles, independent, objective and oriented towards improvement and early warning. Paragraph 3 letter $b$ that is conducting the Implementation of the Implementation of Local Government Implementation; and letter e performs supervision in the framework of a certain purpose in accordance with the provisions of legislation. For general supervision, the Minister assigns GISA within the Ministry in accordance with its functions and authorities and is implemented efficiently and effectively and coordinatively, and for technical supervision, the technical minister assigns GISA within the respective ministry of technical ministries in accordance with their functions and authorities and heads of non-assign GISA within the supervisory unit of non-ministerial government institutions in accordance with their functions and authorities and implemented efficiently and effectively and coordinatively.

The Government Regulation also clarifies the coordination mechanism between GISA and Law Enforcement Officials in handling public complaints. Article 27 paragraph 1 states that the regional head, deputy regional head, and head of regional apparatus shall carry out follow-up on the results of guidance and supervision. Article 37 paragraph 3 stipulates that the administrative sanction imposed is a follow up of the results of the Supervision of Regional Government Implementation and as part of the development of the Regional Government Implementation. In paragraph 4 letter e, it is stated that administrative sanctions may take the form of licensing authority.

Presidential Regulation Number 192 Year 2014 Concerning Finance and Development Supervisory Board (BPKP), in Article 1 paragraph 1 BPKP, is GISA. Article 2 states that BPKP has the duty to administer government affairs in the field of state/regional financial supervision and national development. Furthermore Based on Article 1 point 11 of Presidential Regulation Number 4 Year 2015 on the Fourth Amendment of Presidential Regulation Number 54 Year2010 concerning Procurement of Government Goods/Services, it is stated that GISA is a supervisory apparatus through audit, review, evaluation, monitoring and other supervisory activities against the organization of tasks and functions. Presidential Regulation Number 7 Year 2015 concerning the Organization of State Ministries, Article 17 
states that the State Ministry's Inspectorate General Elements, Inspectorate General, is headed by the Inspector General, and is under and accountable to the Minister. Article 18 states that the Inspectorate General has the duty to organize internal control within the Ministry.

Presidential Instruction Number 9 Year 2014 on Improving Quality of Internal Control System and Reliability of Internal Audit Function Implementation order to achieve people's welfare. In the second dictum of the Presidential Decree, it is necessary to intensify GISA's role in improving the quality, transparency, and accountability of state/regional financial management and national development as well as increasing corruption prevention efforts.

In Article 3 of Regulation of the Minister of Home Affairs Number 110 Year 2017 Concerning Regional Government Control Policy of 2018 states that the Policy of Supervision of Regional Government 2018 aims to: a. synergize supervision by Ministries, technical ministries/non-ministerial government institutions, governors as representatives of central government, provincial and district/municipal governments towards the implementation of local government; $b$. improve the quality assurance of local governance; and c. increase public trust over GISA supervision. Article 3 Paragraph 3 The focus and objectives of the Supervision of Implementation of Regional Government are contained in the Attachment of this Ministerial Regulation, including supervision of the management of natural resources. Furthermore, in Article 5 stated that the Implementation of the Policy of Supervision of the Implementation of Local Government in accordance with its authority is carried out by: a. Inspectorate General of the Ministry of Home Affairs; b. Inspectorate General of the technical ministry/major inspectorate/ inspectorate of non-ministerial government institutions; c. the governor's device as a representative of the central government; d. provincial inspectorate; and e. district/city Inspectorate.

Based on the identification of GISA authority arrangements in some of the above provisions indicate that the legal status of GISA as a normative oversight body has been set clearly and clearly. The supervisory and guidance authority inherent 
in GISA enables GISA to directly supervise and engage in any implementation of government activities, from the planning, implementation, monitoring and evaluation of activities. ${ }^{24}$ If the authority possessed by GISA is executed properly and optimally, then the various possibility of administrative violation either harms State finance or not harm will be prevented from the beginning.

However, the question appears that why the legal position and authority of GISA, the legal norms related to what are having the main task and function which are very clear, but in practice the administration of governance is still a lot of lawlessness. Corruption, collusion, and nepotism action continues to occur in various sectors, including corruption, collusion, and nepotism in the process of natural resource licensing. What is wrong with GISA? Is the quality of the apparatus or its weak human resources? Or does GISA not know the limits of its main duties and functions? Or does GISA intentionally allow various irregularities committed by the state bureaucratic apparatus? Or there is no GISA boldness to monitor and reprimanding the leadership if the leader commits an offense?

What is the authority of GISA has been clearly regulated, yet regarding to the appointment in the position and responsibility for the implementation of the tasks and functions of GISA still contains weaknesses. This weakness can be seen in the provision of Government Regulation Number 60 Year 2008, which states that BPKP is GISA that directly responsible to the President, while the Inspectorate General or the internal supervisor of the agency directly responsible to the minister/head of the institution similar with the Inspectorate in the area. Provincial Inspectorate and Regency/City Inspectorate, each responsible directly to the Governor and Regent/Mayor. ${ }^{25}$

Given the accountability structure of GISA as such that stuff, it means that the position of GISA is under the leadership of the state, the leadership of the Ministry/ Institution, or the regional head. This condition of accountability structure will

${ }^{24}$ See the provisions of Article 379 and Article 380 of Law Number 23 Year 2014 on Regional Government. LAN, Kajian Isu-Isu Strategis: Penguatan Peran Aparat Pengawasan Intern Pemerintah (APIP) Pasca UU Administrasi Pemerintahan (Research Center HANSAN 2016).[49].

${ }^{25}$ See the provisions of Article 1 number 4, 5, 6, and number 7 of Government Regulation Number 60 of 2008 on Government Internal Control System (SPIP). 
certainly reduce the independence of GISA. Similar with GISA in the region, GISA legal status equivalent to the head of the agency or equivalent also with the head of the agency who has the authority to take care of licensing and is under the Secretary of the Regions. GISA is appointed and accountable to the regional head through the Regional Secretary. This condition certainly makes the independence of GISA in carrying out duties and functions that are not optimal authority, because it becomes a psychological burden for GISA.

Thus, it can be understood if GISA has not been able to carry out its duties and functions independently of authority, because there is a sense of concern or hesitation or "ewuh pakewuh", because that will be examined concerning the activities undertaken by certain officials (equivalent to echelon of GISA) or the head of the region as his superior. So if there are findings of irregularities related to natural resource licensing activities, it can be ascertained that the supervisory officers "do not dare" to take action. The problem lies not in the institutional legal position of GISA, but lies in the regulation of appointment mechanism and personal responsibility of GISA.

Institutionally GISA's legal standing is still an internal part of government agencies, but functionally it must be autonomous and independent. Therefore, in order to be autonomous and independent in the implementation of supervision, the appointment in the position and responsibility of the execution of the duties and functions of GISA is not carried out by the relevant internal agency, but carried out by the agency which is vertically one level above it. For example GISA at district/ city level by Governor, GISA at provincial level by Home Affairs Minister, GISA Ministry/Non-Minister by President.

The construction and structure of such accountability are in line with what Raharjo $^{26}$ proposed, Chairman of corruption, collusion, and nepotism $(\mathrm{CCN})$ that

\footnotetext{
${ }^{26}$ Agus Raharjo, Presented at the Seminar on "Strengthening the Role of Government Internal Supervisory Apparatus (GISA) in Combating Corruption in Post-Administration Law", Jakarta, August 10, 2016. See http://www.lan.go.id/.../seminar-nasional-powering-role-apparatus-oversight-intern-government, downloaded on 10th of January 2018.
} 
the Inspectorate or GISA should be independent, so that it is free to supervise, not dependent on the position of the place where the inspectorate works. In connection with the concept of administrative law, Simatupang also stated that the role of the Inspectorate General is important in preventing abuse of authority. Even according to him, in a good system, it is necessary to have ministries that do the planning and the ministry in charge of supervision.

\section{The Authority of Government's Internal Supervisory Apparatus (GISA) is Related to the Supervisory Function in Natural Resource Licensing Governance to Prevent of Corruption, Collusion and Nepotism}

The practice of corruption in the natural resources sector such as abuse of authority, bribery, giving of facilitation payment, illegal fees, gratification, is common in this country. Ironically, although the eradication efforts have been continuously done, but the practice of corruption, collusion, and nepotism is still ongoing, ${ }^{27}$ there is even a tendency of operation mode which is more sophisticated and congregation, thus making it more difficult to eradicate. The management of natural resources licensing that often deviates so far, has caused the risk of pollution and destruction of natural resources and environment. The environmental contamination and destruction of natural resources is a social burden that eventually the community is losing and the government must bear the cost of recovery. ${ }^{28}$

${ }^{27}$ The eradication of corruption in Indonesia has been going on since the 1950s. Started when the abuse of power of economic minister Iskak Tjokroadisuryo (cabinet Ali Sastroamidjojo I) was in the form of import licenses from Benteng Politics to his friends who were then sold to Chinese businessmen (Ali-Baba program).Sigit Andy Cahyono, [et.,al]'Dampak Pemberantasan Korupsi Terhadap Perekonomian, Emisi Karbon Dan Sektor Kehutanan Indonesia: Corruption Eradication Impacts on The Economy, Carbon Emissions and Forestry Sector in Indonesia' (2015) 22 Manusia dan Lingkungan $<$ https://jurnal.ugm.ac.id/JML/article/view/18766>.[390].

${ }_{28}$ The quality of the environment continues to decline year by year. Based on the Indonesian Environment Status (SLHI) in 2013, the quality of river water tends to decrease, as seen from the increasing percentage of river water monitoring points in Indonesia with the severe polluted status from $62 \%$ in 2009 to $80 \%$ in 2013 , which is shown by the concentration of CO and NO2 that tend to increase in 2012, and the rate of deforestation increased from 0.45 million (Ha) in the period 20092011 to 0.61 million (Ha) in the period 2011-2012. Meidiza Dwi Orchidea, 'Efektivitas Pelaksanaan Kebijakan Dana Dekonsentrasi Terhadap Peningkatan Kualitas Lingkungan Hidup’ (2016) 6 Pengelolaan Sumberdaya Alam dan Lingkungan/JPSL < http://journal.ipb.ac.id/ index.php/jpsl/article/ view/12250>.[200-201]. 
Good natural resource licensing governance is determined by competence, moral behavior and apparatus motivation, and supported by effective and efficient supervision system, appropriate technology tools, adequate infrastructure and facilities, so as to produce professional and clean natural resource licensing governance from CCN. Proper management of natural resource licensing should start from the internal organization, through the authority of internal controls to prevent corruption, such as misuse in the granting and execution of licenses and other forms of abuse of authority. This is important given the dynamics of the development of government affairs, the magnitude of the potential for irregularities in the field of licensing, and the increasingly complex regulation of the natural resources affairs of the SDA, since each sector has its own regulation. Implementation of supervisory authority by GISA in the governance of natural resources permit is directed to prevent the occurrence of irregularities as well as efforts to overcome them.

Supervision is a part of preventive law enforcement efforts. Preventive law enforcement is intended to prevent unlawfulness. Theoretically, according to Friedman that the success or failure of law enforcement depends on three elements of the legal system, namely the structure of law, substance of the law (legal substance) and legal culture. ${ }^{29}$ These three legal subsystems will be interconnected and affect each other.

Referring to the theory of Friedman, with still many violations of law in the field of natural resource licensing, it seems the problem lies in the behavior of the authorities that is on the structure and culture of law. If so, it is necessary to improve the legal structure and legal culture of the administrative law enforcement officers, both GISA and officials who have the authority to organize natural resource licensing, as well as the legal culture of the community. Problem of legal substance from GISA institute more to arrangement of appointment mechanism in position and responsibility of execution of authority of GISA. As for the legal substance

\footnotetext{
${ }^{29}$ Lawrence M.Friedman, Sistem Hukum: Perspektif Ilmu Sosial (Transaltor: M. Khozim. ed, Nusa Media 2011).[15-17].
} 
associated with material law and the law of procedural licensing of natural resources has been adequately regulated in various sectoral regulations. ${ }^{30}$

Therefore, in the legal system of supervision, in the legal structure and legal subsystem, both concerning the capacity and capabilities of GISA is necessary to improve and improve efforts. This is because in reality, corruption, collusion, and nepotism in natural resource licensing often occurs in various forms and operation mode, for example business actors do not meet licensing requirements, but permit decisions are still given; there is an omission on the granting of licensing obligations by business actors after the operational activities; there is an omission to a business actor who clearly does not have a business license/activity but remains operational; the application for a permanent permit is granted despite breaking the rules. Such legal facts indicate that there have been acts of corruption, which would have an adverse effect on the State's finances, damaging natural resources and causing disasters for the environment.

In the concept of administrative law, known as contraries actus principle. This principle means that a state administrative body or official who has the authority to issue a permit decision by itself is also authorized to cancel or revoke it. ${ }^{31}$ The essence of this principle is that the authorities withdraw a decision that is its own builder and cannot be done by another party. Likewise, the decision on natural resource licensing, if there is a violation of law, its law enforcement should be done by the official who issued the permission decision, ${ }^{32}$ but often the opposite happens, unlawful bodies or officials of administration (onrechtmatige

${ }^{30}$ The sectoral regulations are Forestry Law, Mining Law, Maritime Law, Plantation Law, Geothermal Law, Act (UU) KSDAHE, Act (UU) TR, Act (UU) PPLH, Act (UU) AS, Act (UU) ASN, Act (UU) AP, and various implementing regulations.

31 Philipus M. Hadjon and Tatiek Sri Djatmiati, Argumentasi Hukum (Gadjah Mada University Press 2009).[25].

32 See the provisions of Article 72 of the UUPPLH, stating that the ministers, governors, or regents/mayors in accordance with their respective powers shall supervise the compliance of the party responsible for the business and/or activity on the environmental permit. In Article 112 UUPPLH also mentioned that any authorized official who intentionally does not supervise the compliance of the party responsible for the business and/or activity against the laws and environmental permit, is threatened with imprisonment. 
overheadsdaad). ${ }^{33}$ This should not happen, considering the main task of the government is to carry out government functions that provide administrative services, implement and enforce administrative law.

Facing such legal facts, people who are adversely affected by activities/ businesses and (interests) of the environment are often victimized and helpless, where to complain about their fate. This is where the urgency and the need for the function of GISA as an independent and professional supervisory body (law enforcement officer), in order to prevent such off the law (onrechtmatige overheadsdaad) so it can be prevented and dealt with in accordance with the prevailing regulations.

Supervision by GISA is a preventive step in the framework of administrative law enforcement. Related to this, Haan, states that the enforcement of administrative law is often interpreted as the application of administrative sanctions. Sanctions are the application of power tools in reaction to violations of administrative law norms. ${ }^{34}$ While ten Berge states that the administrative law enforcement instruments include two things: supervision and application of sanctions. Supervision is a preventive measure to carry out compliance, while the application of sanctions is a repressive measure to enforce compliance. ${ }^{35}$ The application of sanctions is intended to stop the violation, since the character of administrative sanctions is reparatoir, which means to correct or restore the original condition as it was before the offense occurred.

The supervisory authority that GISA has in mind must be functionalized in natural resource management. Efforts to function GISA in the governance of natural

${ }^{33}$ Onrechtmatige overheadsdaad, Philpus M. Hadjon and Tatiek Sri Djatmiati declare that what is meant by unlawful acts by governmental bodies or officials is a violation of law against all decisions and or factual actions of government administration carried out by governmental bodies or officials granted the authority to administer government affairs, with the characteristics of public law disputes and the benchmarks for the validity of a decision and or factual action are in the legality aspect of the legislation and the general principles of good governance Agus Budi Susilo, 'Reformulasi Perbuatan Melanggar Hukum Oleh Badan Atau Pejabat Pemerintahan Dalam Konteks Kompetensi Absolut Peradilan Tata Usaha Negara' (2013) 2 Hukum dan Peradilan <http://www. jurnalhukumdanperadilan.org/index.php/jurnalhukumperadilan/article/view/119>.[301].

${ }^{34}$ P. De.Haan, Bestuursrecht in Sociale Rechtstaat, Deel 2 Bestuurs Handelingen En Waarborgen (Kluwer Deventer 1986).[91-90].

${ }^{35}$ J.B.J.M. ten Berge, Course Book, Recent Development in General Administrative Law in The Neteherlands (Utrecht 1994).[21]. 
resource licensing, in line with the legal theory that law can be used as a social engineering instrument (law as a tool of social engineering), ${ }^{36}$ to make community renewal. ${ }^{37}$ Even the law as an instrument to direct society toward the goal to be achieved, if necessary, the law can be used to eliminate negative societal habits, ${ }^{38}$ in a broader sense including the negative habits of the apparatus and officials, but certainly in the context of a legal State based on Pancasila and the 1945 Constitution.

Related to this by referencing to the theory of law above, then to functionalize GISA in natural resources licensing governance should be made efforts to improve on some aspects. These efforts, which are:

1. Aspects of institutional structures:

a. The institutional structure of GISA, while still an internal part of the government agency, but in the mechanism of arranging appointment and accountability of the duties and functions of the apparatus are arranged in stages, so GISA can work autonomously and objectively;

b. The scope of performance under GISA's institutional authority is not limited to government activities related to the use of State and local budgets (APBN/ APBD) only (projects), but also to other government activities or actions including those related to potential natural resource governance ;

2. Aspects of Quality of Human Resources (HR):

a. Need to improve the competence or understanding of GISA human resources in the field of legal science including law in the field of natural resources, both regarding material law and procedural law (administration, civil and criminal);

b. GISA human resources must have a mentality, integrity, and character of good behavior, therefore in the process of recruitment is based on clear and

\footnotetext{
${ }^{36}$ Roscoe Pound, put forward the concept of "Law as a tool of social engineering", that law can not only be used to perpetuate power, but law can function as a means of social engineering Lili Rasyidi, Dasar-Dasar Filsafat Hukum (Citra Aditya Bakti 1990).[47].

37 According to Mochtar Kusumaatmadja, the law is not enough to act as a tool but as a means of community renewal. Mochtar Kusumaatmadja, Pembinaan Hukum Dalam Rangka Pembangunan Hukum Nasional (Bina Cipta 1986).[9].

38 Satjipto Rahardjo, Ilmu Hukum (Alumni 1986).[110-111].
} 
measurable standard of competence; because supposing to keep the floor clean to stay clean, must use a clean broom.

\section{Aspects of Regulations}

a. Establish specific regulatory regulation related to the Internal Control System, as a legal protection for the exercise of oversight authority by GISA, including the regulation of authority in natural resource management, making it clear that the legal status of GISA as an autonomous/independent supervisory agency. The regulation is also intended to harmonize GISA institutional arrangements with existing regulations (such as the Regional Government Law, UUAP);

b. Establish standard operating procedures (SOP) with respect to GISA performance mechanisms, SOP coordination mechanisms with external regulatory agencies such as BPK, Ombudsman, DPR/DPRD, KPK, Polri, Attorney General, and Menpan RB or related NGOs.

\section{Conclusion}

The authority of GISA in performing the functions of general and technical supervision has been regulated in various regulations but still there are weaknesses related to the appointment in the position and responsibility mechanism of the implementation of GISA duties and functions, because it is not done in stages, so the performance results are potentially not objective. GISA should be able to exercise its authority well in order to prevent corrupt practices and other irregularities, since the authority inherent in GISA enables GISA to guard and engage directly in every function of government. GISA should be an important instrument to realize good governance, clean and free from good and clean governance, not to the contrary that creates new corruption, collusion, and nepotism's deeds of "negative conspiracy" (negative mutualism symbiosis), because the relationship of superiors with subordinates.

The authority of GISA which specifically relates to supervisory functions in natural resource licensing governance has not been explicitly regulated in existing regulations. However, GISA remains authorized to monitor the governance of natural 
resource licensing. Therefore, the issuance of all permit decisions and other natural resource licensing governance is the implementation of government functions, while internal control in the administration of government functions is the authority of GISA, as regulated in Regional Law (UU Pemda), Government Administration (UUAP), Government Law Number 12 Year 2017 and related provisions.

In order for GISA as a supervisory body (administrative law enforcement) to exercise its authority properly and objectively, GISA institutions shall be autonomously regulated, in the sense that GISA remains as an internal part of government organization (as the name implies), but is functionally independent. To function autonomously/independently, appointments in GISA positions and liability mechanism must be regulated and set hierarchically/gradually.

Currently, special regulation related to internal control system is required. The urgency of the regulation, along with the dynamics of the development of government affairs, the magnitude of the potential for irregularities in the licensing field, and the increasingly complex regulatory affairs of natural resources, as each sector has its own regulation and policy. Heads of ministries/non-ministries and local governments are GISA shareholders. Therefore, in relation to the governance of natural resource licensing to improve the capacity and functional capability of GISA in the sector, it is necessary to support and commitment from all stakeholders, and the leadership of GISA itself, so that efforts to prevent and eradicate corruption, collusion, and nepotism acts become a necessity.

\section{Bibliography}

Absori and Nunik Nurhayati, 'Kebijakan Perizinan, Sengketa Lingkungan Hidupdan Kepentingan Investasi' (2017) 7 Jurisprudence $<$ https:// www.google.com/search?q=Absori + dan + Nunik + Nurhayati\%2C+"Kebijakan+Perizinan $\% 2 \mathrm{C}+$ Sengketa + Lingkungan + Hidupdan + Kepentingan+Investasi"\%2C+(2017)+7+Jurisprudence.\&rlz=1C1CHBD_idID823ID823\&oq=Absori+dan+Nunik+Nurhayati\%2C+“Kebijakan+Perizinan $\% 2 \mathrm{C}+$ Sengketa $>$.

Agus Budi Susilo, 'Reformulasi Perbuatan Melanggar Hukum Oleh Badan Atau Pejabat Pemerintahan Dalam Konteks Kompetensi Absolut Peradilan Tata 
Usaha Negara' (2013) 2 Hukum dan Peradilan $<$ http://www.jurnalhukumdanperadilan.org/index.php/jurnalhukumperadilan/article/view/119>.

Bambang Arwanto, 'Perlindungan Hukum Bagi Rakyat Akibat Tindakan Faktual Pemerintah’ (2016) 31 Yuridika <https://e-journal.unair.ac.id/YDK/article/ view/4857>.

BAPPENAS, Indonesian Climate Change Sectoral Roadmap (ICCSR) Summary Report Forestry Sector, (BAPPENAS 2010).

Fenty U Puluhulawa, 'Pengawasan Sebagai Instrumen Penegakan Hukum Pada Usaha Pertambangan Mineral Dan Batubara' (2011) 11 Dinamika Hukum $<$ http://dinamikahukum.fh.unsoed.ac.id/index.php/JDH/article/view/189>.

G.H. Addink, Reader, Principles of Good Governance (Faculty of Law, Economic, and Governance, University of Utrecht 2010).

Government Regulation Number 60 Year 2008 on Government Internal Control System (SPIP) (Statute Book of 2008 No. 127, Supplement to Statute Book Number 4890).

Government Regulation Number 12 Year 2017 on the Development and Supervision of Local Government Implementation (Statute Book of 2017 No. 73, Supplement to Statute Book Number 6041).

Hamrat Hamid and Bambang Pramudyanto, Pengawasan Industri Dalam Pengendalian Pencemaran Lingkungan (1st edn, Granit 2007).

Iskandar, Hukum Kehutanan, Prinsip Hukum Pelestarian Fungsi Lingkungan Hidup Dalam Kebijakan Pengelolaan Kawasan Hutan Berkelanjutan (Mandar Maju 2015).

—_, 'Hukum Perizinan Sebagai Instrumen Pencegahan Kerusakan Sumber Daya Alam Dan Lingkungan Hidup', Orasi Ilmiah, 15 Oktober 2015 (Universitas Bengkulu 2015).

J.B.J.M. ten Berge, Course Book, Recent Development in General Administrative Law in The Neteherlands (Utrecht 1994).

LAN, Kajian Isu-Isu Strategis: Penguatan Peran Aparat Pengawasan Intern Pemerintah (APIP) Pasca UU Administrasi Pemerintahan (Research Center HANSAN 2016).

Law Number 15 Year 2004 Concerning Audit of Management and Responsibility of State Finances (Statute Book of 2004 No. 66, Supplement to Statute Book 
No. 4400).

Law Number 32 Year 2009 on Environmental Protection and Management (Statute Book Year 2009 Number 147, Supplement to Statute Book Number 5059).

Law Number 23 Year 2014 on Regional Government (State Gazette Year 2014 Number 244, Supplement to the State Gazette Number 5587), as amended the latest by Law Number 9 Year 2015 on the Second Amendment to Law Number 23 Year 2015 on Governance Region (State Gazette Year 2015 Number 58, Supplement to the State Gazette Number 5679).

Law Number 30 Year 2014 on Government Administration (State Gazette Year 2014 Number 292, Supplement to the State Gazette Number 5601).

Lawrence M.Friedman, Sistem Hukum: Perspektif Ilmu Sosial (Transaltor: M. Khozim. ed, Nusa Media 2011).

Lili Rasyidi, Dasar-Dasar Filsafat Hukum (Citra Aditya Bakti 1990).

Linda, 'Pengelolaan Sumber Daya Alam Yang Bertanggung Jawab' (Portal Pantauan Hutan, 2015) <http://fwatcher.fwi.or.id/pengelolaan-sumber-dayaalam-yang-bertanggung-jawab/\#_ftn2> accessed 5 January 2018.

Lusia Arumingtyas and Tommy Apriando, 'Ketika Bupati Rita Terjerat Dugaan Suap Izin Sawit Di Kutai Kertanegara' (Mongabay Situs Berita Lingkungan, 2017) <https://www.mongabay.co.id/2017/10/08/ketika-bupati-rita-terjeratdugaan-suap-izin-sawit-di-kutai-kertanegara/> accessed 5 January 2018.

Meidiza Dwi Orchidea, 'Efektivitas Pelaksanaan Kebijakan Dana Dekonsentrasi Terhadap Peningkatan Kualitas Lingkungan Hidup' (2016) 6 Pengelolaan Sumberdaya Alam dan Lingkungan/JPSL < http://journal.ipb.ac.id/index.php/ jpsl/article/view/12250>

Mochtar Kusumaatmadja, Pembinaan Hukum Dalam Rangka Pembangunan Hukum Nasional (Bina Cipta 1986).

Oheo K.Haris, 'Aspek Hukum Pidana Dalam Kaitannya Dengan Perizinan Di Bidang Pertambangan' (2014) 29 Yuridika <https://e-journal.unair.ac.id/ YDK/article/view/376>.

__, 'Good Governance (Tata Kelola Pemerintahan Yang Baik) Dalam Pemberian Izin Oleh Pemerintah Daerah Di Bidang Pertambangan’ (2015) 30 Yuridika $<$ https://e-journal.unair.ac.id/YDK/article/view/4879>.

P. De.Haan, Bestuursrecht in Sociale Rechtstaat, Deel 2 Bestuurs Handelingen En 
Waarborgen (Kluwer Deventer 1986).

Peter Mahmud, Penelitian Hukum (Kencana Prenada Media Group 2005).

Philipus M. Hadjon, 'On the Authority of the Government (Bestuur Bevoegdheid)' (1998) XVI Pro Justitia.

—_, 'PTUN Dalam Konteks UU No. 30 Tahun 2014 Tentang Adminstrasi Pemerintahan', Seminar Nasional: Administrative Law Update 2017 (Hyatt Regency Yoyakarta 2017).

Philipus M. Hadjon and Tatiek Sri Djatmiati, Argumentasi Hukum (Gadjah Mada University Press 2009).

Presidential Regulation Number 192 Year 2014 Concerning Finance and Development Supervisory Board (State Gazette Year 2014 Number 400).

Presidential Regulation Number 4 Year 2015 Concerning the Fourth Amendment of Presidential Regulation Number 54 Year 2010 on Procurement of Government Goods/Services (State Gazette Year 2015 Number 5).

Presidential Regulation Number 7 Year 2015 on Organization of State Ministries (State Gazette Year 2015 Number 8).

Presidential Instruction (Inpres) Number 9 Year 2014 on Improving Quality of Internal Control System and Reliability of Internal Audit Function Implementation in Order to Achieve People's Welfare.

Regulation of the Minister of Home Affairs Number 110 Year 2017 on The Policies of Supervision of Local Government Implementation Year 2018.

Regulation of the Minister of Environment Number 7 Year 2014 on Environmental Losses Due to Pollution and/or Environmental Degradation.

Restu Mulyana, 'Potensi Korupsi Di Bidang Perizinan' (harian.analisadaily.com, 2016) $<$ http://harian.analisadaily.com/opini/news/potensi-korupsi-di- fieldlicensing/260241/2016/09/01> accessed 5 January 2018.

Resty Armenia, 'Jokowi Kaget Terima Laporan Soal Kondisi Pengawasan Internal' (CNN Indonesia, 2015) <https://www.cnnindonesia.com/ nasional/20150513151334-20-53103/jokowi-kaget-terima-laporan-soalkondisi-pengawasan-internal> accessed 10 January 2018.

Tempo.co, 'Amran Batalipu of Buol Regent' (Tempo.co, 2017) <https://nasional. tempo.co/read/900315> accessed 26 September 2017. 
Toto Pribadi, 'The Number of OTTs by the KPK, From 2005 to October 2017' (VIVA.co.id, 2017) <http://www.viva.co.id/berita/nasional/965440-daftarott-kpk-dari-tahun-ke-tahun-2017-paling-sibuk> accessed 10 January 2018.

UNDP, 'Indeks Tata Kelola Hutan' (Industri bisnis, 2014) <http://industri.bisnis. com/read/20150522/99/435928/indeks-tata-kelola-hutan-2014-diluncurkan> accessed 5 January 2018.

Salim HS and Erlies Septiana Nurbani, Penerapan Teori Hukum Pada Penelitian Dan Disertasi (PT RadjaGrafindo Persada 2013).

Satjipto Rahardjo, Ilmu Hukum (Alumni 1986).

Sigit Andy Cahyono,[et.,al], 'Dampak Pemberantasan Korupsi Terhadap Perekonomian, Emisi Karbon Dan Sektor Kehutanan Indonesia: Corruption Eradication Impacts on The Economy, Carbon Emissions and Forestry Sector in Indonesia' (2015) 22 Manusia dan Lingkungan $<$ https://jurnal.ugm.ac.id/ JML/article/view/18766>.

HOW TO CITE: Iskandar, 'Authority of Government Internal Supervisory Apparatus in Licensing of Natural Resources to Prevent Corruption, Collusion and Nepotism’ (2019) 34 Yuridika. 
--This page is intentionally left blank-- 